\title{
FELO PÉREZ MOGOTE (VIÑALES, PINAR DEL RÍO, CUBA): TYPICAL SHAPING OF ROCK SURFACE BELOW DENSE TROPICAL VEGETATION
}

\author{
MOGOTA FELO PÉREZ (VIÑALES, PINAR DEL RÍO, KUBA): \\ TIPIČNO OBLIKOVANJE KAMNITEGA POVRŠJA POD GOSTIM \\ TROPSKIM RASTJEM
}

\author{
Manuel Roberto GUTIÉRREZ DOMECH ${ }^{1}$, Martin $\mathrm{KNEZ}^{2,3}$ \& Tadej SLABE ${ }^{2,3}$
}

\begin{abstract}
UDC 551.435.8(729.1)

Izvleček

UDK 551.435.8(729.1)

Manuel Roberto Gutiérrez Domech, Martin Knez \& Tadej Slabe: Felo Pérez Mogote (Viñales, Pinar del Río, Cuba): Typical Shaping of Rock Surface below Dense Tropical Vegetation The results of studying the geomorphological, geological, and lithomorphogenetic karst characteristics of the selected mogote reveal its unique but typical formation under the given conditions. Micritic heavily tectonically crushed and heavily recrystallized limestone with stylolites dominates throughout the entire geological column and is very uniform. Analyzing $\mathrm{Ca}$ and $\mathrm{Mg}$ with complexometric titration method of rock samples showed very pure total carbonate and exceeds $96.5 \%$. Rock composition anables development of clear development of rock features, the smallest, as well. The specific rock relief of the mogote bears witness to the gradual denudation of the rock and the transformation of subsoil rock forms into forms carved by rainwater and water creeping down the walls. The article brings new knowledge about special but typical shaping of the rock under dense tropical vegetation, this time under vegetation covering the mogote. On denuded surfaces that emerged from the soil, for this circumstances characteristic rock features develop under the weathered debris that accumulates under dense vegetation. Different rock beds in the studied mogote respond in a similar way to karstification.

Keywords: karst, karren, rock relief, Viñales, Pinar del Río, Manuel Roberto Gutiérrez Domech, Martin Knez \& Tadej Slabe: Mogota Felo Pérez (Viñales, Pinar del Río, Kuba): tipično oblikovanje kamnitega površja pod gostim tropskim rastjem

Izsledki proučevanja kraško geomorfoloških, geoloških in litomorfogenetskih značilnosti izbrane mogote razkrivajo njeno svojevrstno, a za predstavljene razmere značilno oblikovanje. Mikritni močno tektonsko zdrobljen in močno rekristaliziran apnenec s stiloliti prevladuje skozi ves geološki profil. Določevanje Ca in Mg v kamnini z metodo kompleksometrične titracije je pokazalo zelo čist karbonat, ki presega 96,5\%. Sestava skala omogoča jasen razvoj skalnih oblik, tudi najmanjših. Poseben je skalni relief mogote, ki priča o postopnemu razgaljanju skale in preoblikovanju skalnih oblik, ki so nastale pod prstjo, v tiste, ki jih dolbeta deževnica in voda, ki polzi po stenah. Članek prinaša novo spoznanje o posebnem a značilnem skalnem relief, ki se razvija pod gostim tropskim rastjem, tokrat pod poraščenostjo mogote. Na površinah, ki so razgaljene izpod prsti, se pod gostim rastjem nabira preperelina in pod njo nastajajo za te razmere značilne skalne oblike. Različne kamninske plasti raziskovane mogote zakrasevajo podobno. Ključne besede: kras, škraplje, skalni relief, Viñales, Pinar del Río, Kuba.

\footnotetext{
${ }^{1}$ Instituto de Geología y Paleontología, Departamento de Paleontología y Museo, Via Blanca 1002 y Linea del Ferrocarril, San Miguel del Padron, La Habana, CP 11600, Cuba, email: rgdomech@jgp.gms.minbas.cu

${ }^{2}$ Karst Research Institute, Research Centre of the Slovenian Academy of Sciences and Arts, Titov trg 2, SI-6230 Postojna, Slovenia and UNESCO Chair on Karst Education, University of Nova Gorica, Titov trg 2, SI-6230 Postojna, Slovenia, e-mails: knez@zrc-sazu.si,slabe@zrc-sazu.si

${ }^{3}$ Yunnan University International Joint Research Center for Karstology, Xueyun rd. 5, CN-650223, Kunming, China, e-mails: knez@zrc-sazu.si, HYPERLINK "mailto:slabe@zrc-sazu.si" slabe@zrc-sazu.si
}

Received/Prejeto: 03.01.2014 


\section{INTRODUCTION}

Pinar del Río province, the westernmost area of both the Cuban island and the Archipelago territories, extends over $8,800 \mathrm{~km}^{2}$ and has 592,000 inhabitants.

The area under study is located in the Viñales Valley (Figs. 1, 2), a polje that developed between the Up- per Jurassic-Lower Cretaceous limestone of the Sierra de los Organos mountain range and the hills of Pizarras del Sur, the southern slate hills composed of dark grey, fine and medium grained limestone interlaid with lutite and grey or dark grey clayey shale. With the Sierra del

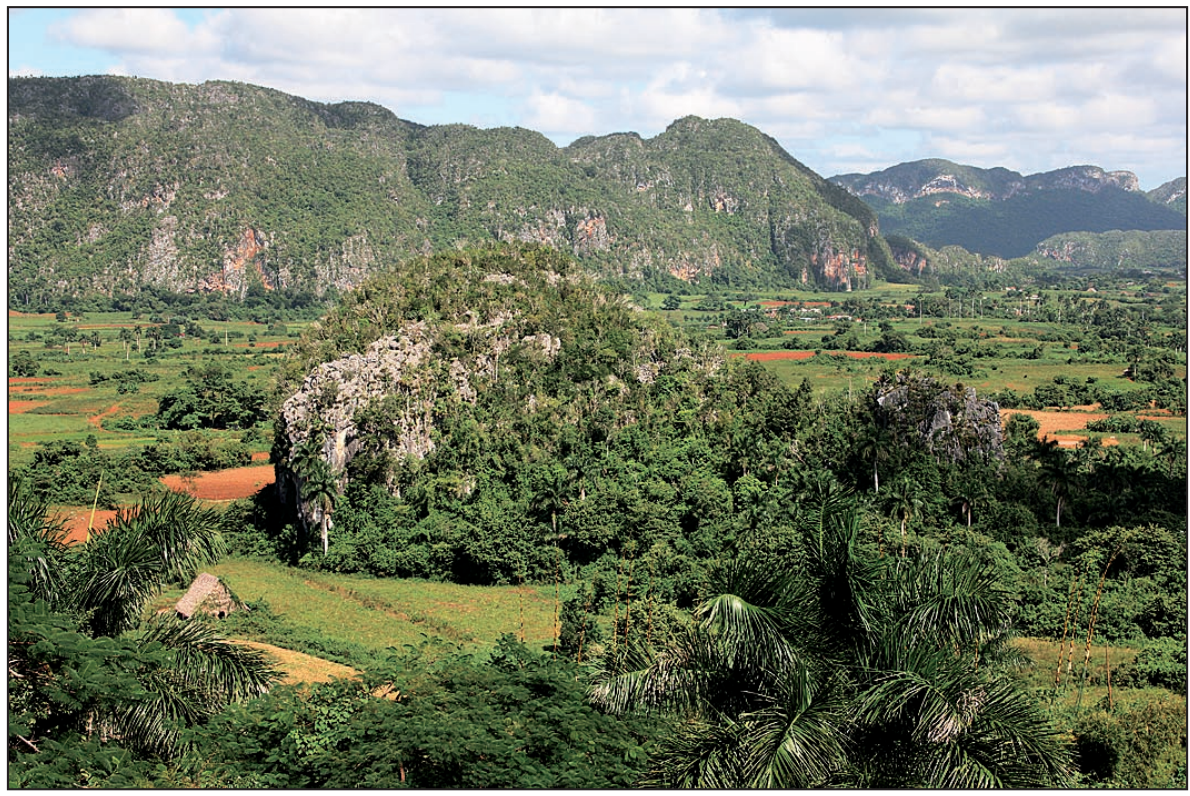

Fig. 1: Felo Pérez in mogote Viñales Valley.

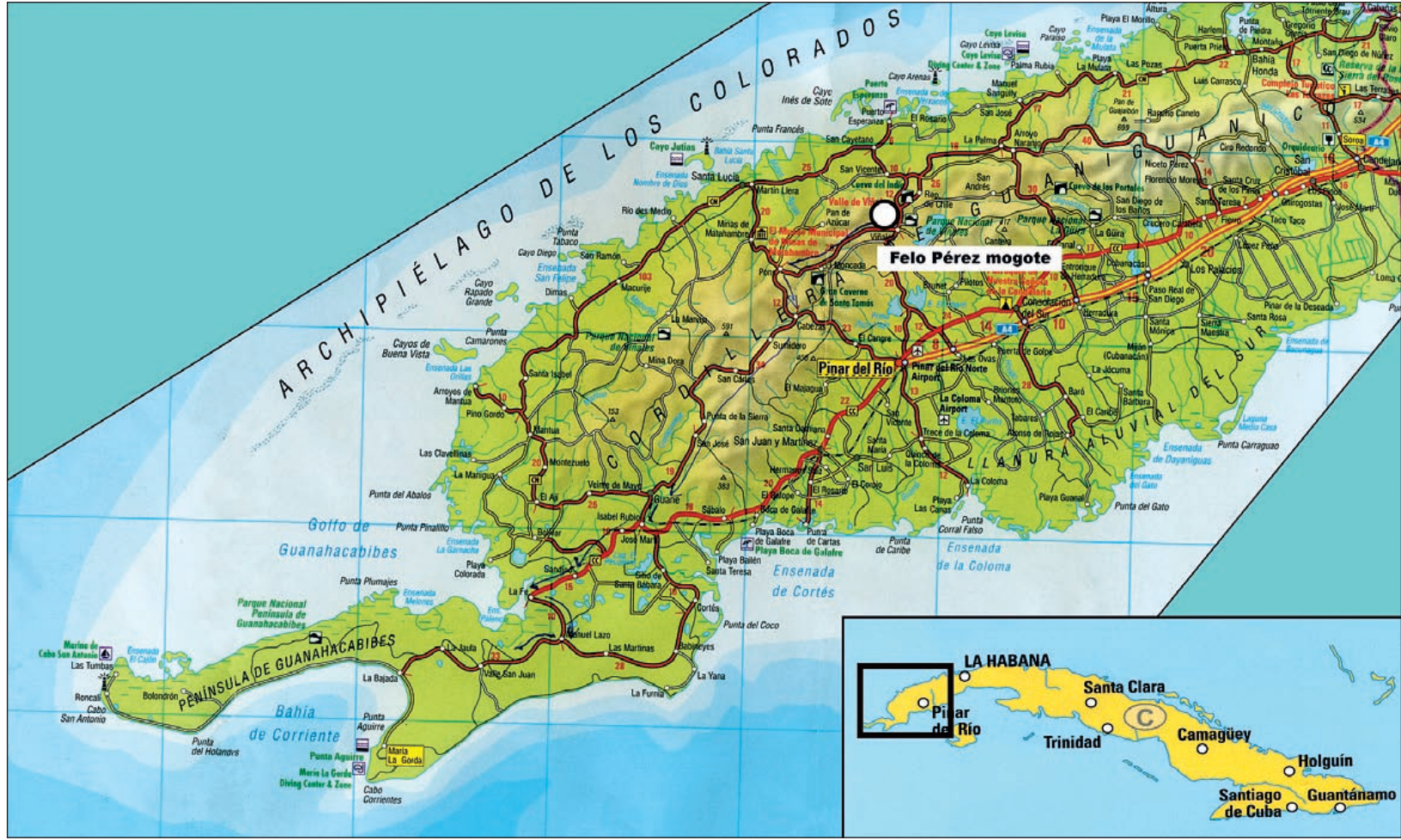

Fig. 2: The location of Felo Pérez mogote. 
Rosario Mountain Range they build the Guaniguanico Mountain Chain. The latter is the main orographic group in the west part of the country (Gutiérrez Domech \& Rivero Glean 1999). It is located within the central to northern area of the province with an approximate SWNE orientation.

The higher elevations of Viñales are the Sierra La Guasasa mountain at $441 \mathrm{~m}$ high and the El Mogote del Valle mogote at 402 meters high.

The Felo Pérez mogote is located in the Viñales Valley, a few tens of meters from the contact zone of shale, silicite, and sandstone of the San Cayetano Formation that forms the Alturas de Pizarras del Sur surrounding the mogotes to the south.

The Viñales Valley and its surroundings were proclaimed a national monument in 1978 and placed on the
UNESCO World Heritage List in 1999. In addition to its cultural value, it contains many natural treasures. There are three different kinds of forest here: evergreen in the mountain dolines, semideciduous over rocky substrate, and mogote forest vegetation covering the tops and scarp walls of such landforms (Gutiérrez Domech \& Rivero Glean 1997).

The most noticeable vegetation species within the national park include the cork palm (Microcycas calocoma), a plant from the Cretaceous considered a living fossil; "ceibón" (Bambocopsis cubensis), an impressive flora typical to mogotes; the "alligator" oak (from the Ekhmaniensis genus); and the little palm tree (Gaussia princeps).

Fauna is mostly represented by invertebrates.

\section{GEOLOGICAL FEATURES OF VIÑALES REGION}

The more extended lithostratigraphic units throughout the Viñales region are Jagua and Guasasa formations (Díaz Otero et al. 2002).

The Jagua Formation (Palmer 1945) is composed of black micritic limestones, clayey to marly schists, and calcareous lutites with calcareous nodes locally known as "cheeses" that contain most of the macrofossils, invertebrates (ammonites, bivalve mollusks), and vertebrates (plesiosaurs, ictiosaurs, pterosaurs, fish).

The Guasasa Formation (Herrera 1961) consists of micritic limestones, sandstones, and chert lenses. The limestone is partly sandy and frequently laminated.

This formation includes several extended members such as the San Vicente Member where massive and thickly layered limestone shapes the higher mogote walls. In the case of the Felo Pérez mogote, the rocks belong to the Tumbadero Member (Herrera 1961). This Upper Jurassic-Lower Cretaceous Guasasa Formation member is composed of micritic limestone and calcilutite with dark interbedded flintstone. In the study area it was not possible to prove the stratigraphic relationships with the underlying and overlying units explained as concordant over the El Americano Member (from the Guasasa Formation) and beneath the Tumbitas Member (Guasasa Formation).

This region is characterized by a complex geological development with typical Alpine tectonics from the Lower Paleogene (Cuban Orogeny) that was overlapped by later general SW-NE vertical neotectonic faulting providing a characteristic "chess board" appearance to the area. Several poljes developed in this intricate landscape as tectonic windows.

\section{KARST FEATURES IN VIÑALES}

It is well known that one of the more prominent tropical karst features of the Organos Mountain Range is the presence of hums or mogotes. The latter term originated in Cuba. The diversity of this karst landform is related to lithology, tectonics, and stratification along with intense karstification processes. Graviclastic processes and rockfalls, temporary or seasonal flooding, and even the "armouring" of the hard crust are also influencing factors.
Mogotes do not act as watersheds since fluvial riverbeds cross through them and rainwater infiltrates them and expands the internal groundwater system.

According to shape, mogotes may be distinguished as cupules, cones, and towers. Each shape corresponds to a particular landform, lithology, and tectonic association.

The fluvial karst torrents commonly surrounding the Viñales mogotes and the Organos Mountain Range 
very close to the valley are characterized by limestone strata of the Guasasa and Jagua Formations cut by acidulated waters through chemical corrosion acting over a fault or diaclasa. Such karst landforms, usually dry, may be present at any height above the base level according to the evolution stage.

In general, fluvial karst torrents are seasonal, filling during the rainy season and hurricane periods. This is the case of Santa Cruz River and other streams in the Guaniguanico Mountain Range, which are quite typical.

The Viñales Valley is known not only for its very typical surface karst landforms but also for its caves, some of them among the largest in the country.

The caves were generally carved by allochthonous waters running from the surrounding non-karstic heights. The sizes of the underground riverbeds indicate that the water table was higher during the genesis than in the present time (Acevedo González \& Gutiérrez Domech 1974). The development and evolution of such fluvial Quaternary dynamic systems is closely related to eustatic fluctuations of the sea level during glaciation periods. These altered surface watercourse profiles, and basin hydrology was subsequently altered as well. This caused different stages of riverbed run-off and sedimentation along with oscillations in the amounts transported due to rainfalls more intense and frequent than at present alternating with drier, even semi-arid stages, and to a process of uplifting and subsiding neotectonic movements.

\section{GEOGRAPHICAL DESCRIPTION OF THE FELO PÉREZ MOGOTE}

The Felo Pérez mogote (Figs. 1, 2, 3) is 190 meters high and covers about $0.25 \mathrm{~km}^{2}$. It is located in the Viñales $\mathrm{Mu}$ nicipality at $22^{\circ} 35^{\prime} 23.59^{\prime \prime} \mathrm{N}, 83^{\circ} 43^{\prime} 23.59^{\prime \prime} \mathrm{W}$, in Pinar del Río province, the westernmost region of Cuba. The location is mapped on the 1:50,000 scale cartographic sheet Consolación del Norte 33483 I of the general map of the Republic of Cuba. The La Feita mogote, some 200 meters away, is fifty meters higher and covers twice the area of the Felo Pérez mogote. The other nearby isolated mogote, El Mogote del Valle, is 402 meters high and covers approximately $6 \mathrm{~km}^{2}$.

The vegetation on the Felo Pérez mogote is mainly endemic: ceibón (Bombax emarginatum), Cayman oak, and various palm trees. A few trees of valuable wood such as oak or mahogany are still scattered here and there in little dolines and hill holes. Formerly abundant with these kinds of species, the region was badly affected by overexploitation, and the original flora is nowadays practically nonexistent. Shrubs cover the layer close to the ground, followed by short structured trees.

The fauna on this elevation consists mainly of invertebrates including several species of butterflies such as Paridis gundlachianus that are endemic to the high water course of the Cuyaguateje River, the longest river in Western Cuba, and terrestrial mollusks such as Zachrisia auricoma, and arachnids such as Heteronebo bermudezi, a kind of scorpion, are very abundant across the entire province.

\section{GEOLOGICAL DESCRIPTION OF THE FELO PÉREZ MOGOTE}

\section{MACROSCOPIC DESCRIPTION}

The rock was studied in detail from the foot to the top of the mogote (Fig. 3) in a southeast-northwest direction. The rock is moderately to thickly stratified with thicknesses ranging from several tens of centimeters to several meters. The prevailing dip angle of beds from the foot to the top changes slightly, is dominantly southward, and ranges between $24^{\circ}$ in $32^{\circ}$. The direction of the dip is between $180^{\circ}$ and $195^{\circ}$.

Numerous thin calcite veins are visible throughout the rock. The rock displays heavy fissuring. Nu- merous primarily subvertical faults, fault zones, and fissures run in all directions. In places the rock is very bituminous. The thickness of the studied profile totals forty meters.

Nineteen rock samples were taken and studied under the microscope. All samples underwent calcimetric analyses as well.

\section{MICROSCOPIC DESCRIPTION}

Throughout the entire geological column the rock is very uniform. Micritic limestone (mudstone) dominates and 


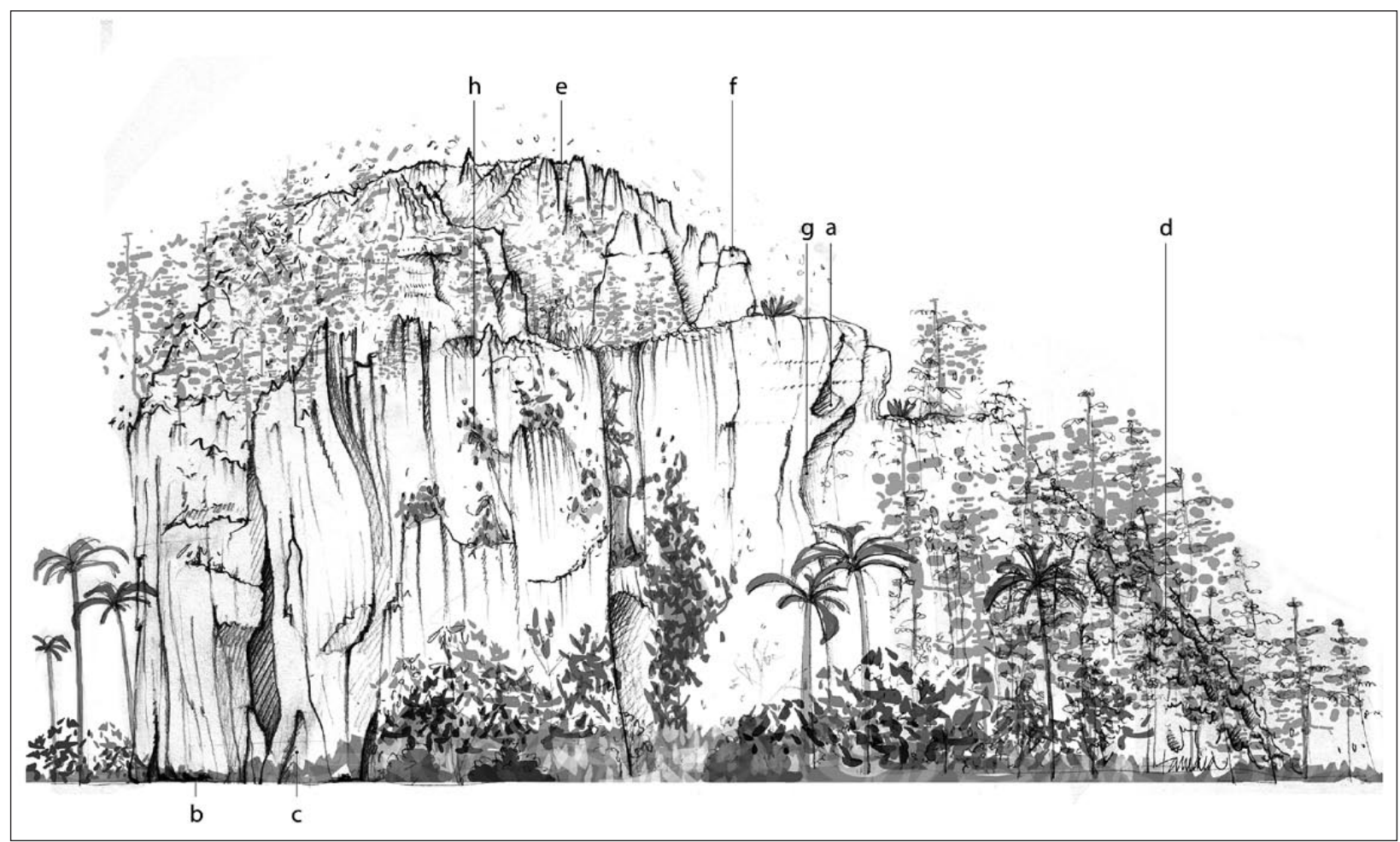

Fig. 3: Rock relief of mogote: a. subsoil hollow, b. subsoil notch, c. subsoil half-bell, d. subsoil cups, e. funnel-shaped notch, f. rain flutes, g. channels, flutes, scallops due to water creeping, $h$. wall channels. Rock samples have been taken along gentle slope of the mogote from its bottom to the top.

in most cases is heavily tectonically crushed. Heavily recrystallized whole and particle fossil remains were found in only two layers. Stylolites were identified in the majority of the samples.

The base of the mogote or the beginning of the profile is composed of a layer of intrabiomicrite (mudstone). Intraclasts 0.2 to $0.5 \mathrm{~mm}$ in diameter occupy up to $20 \%$ and fossil remains up to $10 \%$. The part of the sample with fewer intraclasts and bioclasts displays individual calcispheres up to $45 \mu \mathrm{m}$ in diameter. Allochems are well rounded and show no sorting. The space between allochems is occupied by micrite that is opaque and greyish to brownish in colour. Among the bioclasts, fenestre are visible up to $0.5 \mathrm{~mm}$ in diameter and completely filled with drusy calcite cement. Fibrous calcite cement is observed only as an exception. Micritization of some allochem grains is evident.

The continuation of the profile in samples (mudstone) shows no further allochems. Individual samples contain numerous calcispheres mostly around $45 \mu \mathrm{m}$ in diameter. Signs of tectonic shifting (numerous calcite veins) and compaction (stylolites in sutured contacts) are clearly visible. Calcite veins from $45 \mu \mathrm{m}$ to $8 \mathrm{~mm}$ thick composed of drusy sparite calcite occur in a variety of areas with diverse densities and run in all directions.
The dominant thickness is 20 to $90 \mu \mathrm{m}$ and they belong to different generations.

In most cases, sutured stylolites are younger than calcite veins and run horizontally with or across the stratification. They are filled with insoluble clayey material and in places they display substantial secondary porosity. The amplitude of stylolites ranges between 0.5 and $1.5 \mathrm{~mm}, 1 \mathrm{~mm}$ being the dominant amplitude, which is also the minimal reduction of the bed section thickness. In places stylolites are accompanied by parallel thin calcite veins. Slips along stylolites measure from 0.2 to $1.3 \mathrm{~mm}$. Slips are not evident along different generations of calcite veins.

Some areas of micrite rock (mudstone) are very heavily crushed and indicate pressures parallel to and across the stratification. Here numerous calcite veins of many generations up to $45 \mu \mathrm{m}$ thick dominate. Shorter sections of the profile, however, show no calcite veins but only stylolites with amplitudes up to one centimenter in opaque micrite of greyish to brownish colour.

The top of the mogote is composed of tectonically very fractured and in places completely crushed rock. In the samples we found numerous calcite veins of at least three generations. A cross-section of a one-centimeter thick rock in places displays more than forty calcite veins up to $45 \mu \mathrm{m}$ thick, accompanied by one-centimeter 
Tab.1: Complexometric titration analyses of rock samples.

\begin{tabular}{l|c|c|c|c|c|c|c}
\hline Rock sample & $\mathrm{CaO}$ & $\mathrm{MgO}$ & Dolomite & Total carbonate (\%) & Calcite & CaO/MgO & insoluble residue \\
\hline 1 & 54,28 & 0,16 & 0,74 & 97,21 & 96,47 & 339,25 & 2,79 \\
\hline $2 \mathrm{R}$ & 53,95 & 0,44 & 2,03 & 97,21 & 95,18 & 128,61 & 2,79 \\
\hline $2 \mathrm{I}$ & 54,12 & 0,40 & 1,84 & 97,43 & 95,59 & 135,30 & 2,57 \\
\hline 3 & 54,56 & 0,24 & 1,10 & 97,88 & 96,78 & 227,33 & 2,12 \\
\hline 4 & 54,06 & 0,32 & 1,47 & 97,15 & 95,68 & 168,94 & 2,95 \\
\hline 5 & 54,11 & 0,52 & 2,39 & 97,66 & 95,27 & 104,06 & 2,34 \\
\hline 6 & 53,72 & 0,63 & 1,66 & 96,62 & 94,96 & 3,38 & 3,38 \\
\hline 7 & 55,09 & 0,60 & 2,77 & 99,57 & 96,80 & 91,82 & 0,43 \\
\hline 8 & 54,17 & 0,64 & 2,95 & 98,02 & 95,07 & 84,64 & 1,98 \\
\hline 9 & 54,00 & 0,32 & 1,47 & 97,04 & 95,57 & 168,75 & 2,96 \\
\hline 10 & 54,00 & 0,36 & 1,66 & 97,13 & 95,47 & 150,00 & 2,87 \\
\hline 11 & 54,12 & 0,56 & 2,58 & 97,26 & 94,68 & 96,64 & 2,74 \\
\hline 13 & 54,06 & 0,32 & 1,47 & 97,15 & 95,68 & 168,94 & 2,95 \\
\hline 14 & 53,56 & 0,52 & 2,40 & 96,68 & 96,28 & 103,00 & 3,32 \\
\hline 15 & 54,90 & 0,64 & 2,95 & 99,32 & 96,37 & 85,78 & 0,68 \\
\hline 16 & 55,07 & 0,44 & 2,58 & 99,21 & 96,63 & 125,16 & 0,79 \\
\hline 17 & 54,59 & 0,48 & 2,58 & 98,43 & 95,85 & 113,73 & 1,57 \\
\hline 18 & 53,95 & 0,52 & 2,40 & 97,38 & 94,98 & 103,75 & \\
\hline
\end{tabular}

thick calcite veins filled with drusy sparite. In addition to heavy fissuring of the rock, very crushed layers are evident where sharp-edged particles of the micrite rock 1 to $1.5 \mathrm{~cm}$ in diameter are bonded by sparite drusy cement into compact rock.

\section{CALCIMETRIC ANALYSIS}

We used the complexometric titration method to conduct twenty calcimetric analyses on nineteen rock samples (Tab. 1). We established that the total carbonate in all the samples from the profile exceeds $96.5 \%$. In two samples the content of total carbonate is slightly above $98 \%$ and in three of them well above $98 \%$; the average value of all the samples is $97.6 \%$. All the samples show a high percentage of calcite. Only a quarter of the samples contain less than $95 \%$ calcite, and the average value of all samples is $95.6 \%$. All the samples also contain a significant amount of dolomite. Seven samples have less than $2 \%$ dolomite, one has less than $1 \%$, and no samples contain over $3 \%$. The average value totals a good $2 \%$. Insoluble residue represents a significant proportion of carbonates from the mogote. In six samples the amount of insoluble residue is close to or partly exceeds $3 \%$, and on average the value for all the samples is $2.4 \%$.

\section{IMPACT OF KARSTIFICATION}

The entire geological profile and all the beds that compose the mogote responded in a similar way to karstification.

\section{ROCK RELIEF OF THE MOGOTE}

The unique shaping of carbonate rock in characteristic conditions fosters the development of distinctive and typical rock relief. The numerous rock forms in the relief reveal characteristics of the current shaping of the rock and the development of the mogote.

\section{SUBSOIL ROCK FORMS}

The subsoil shaping of the mogote put an important stamp on the rock relief, and all the most characteristic subsoil rock forms are represented. Subsoil rock features have been presented in their complexity (Slabe \& Knez 2004, Slabe \& Liu 2009, Knez \& Slabe 2009). Subsoil hollows formed (Fig. 3a) along the gently sloping contacts of rock strata, and subsoil shafts formed along vertical fissures. The most conductive hollows grew into smaller caves, and the remainder clearly show initial development periods. Gently sloping hollows are often paragenetically elevated, which means that their greater part lies in the upper rock strata and is often wider and relatively flat at the top. Emptied hollows, which are larger 
as a rule, were shaped by water percolating from the surface that deepened their bottoms. The mouths of smaller hollows and shafts display funnel-like widenings and larger hollows end in pocket-like niches. On the walls, especially in the lower sections above the sediment surrounding the mogote, there are subsoil channels whose diameters reach 0.75 meter. Water creeping evenly over the entire surface along the contact with sediment creates subsoil scallops, some with pocket-like deepenings. Subsoil notches (Fig. 3b) form along the long-term level of sediment surrounding the rock. Their diameter can exceed one meter; at the bottom they are often open and in places, especially along vertical fissures or along in-

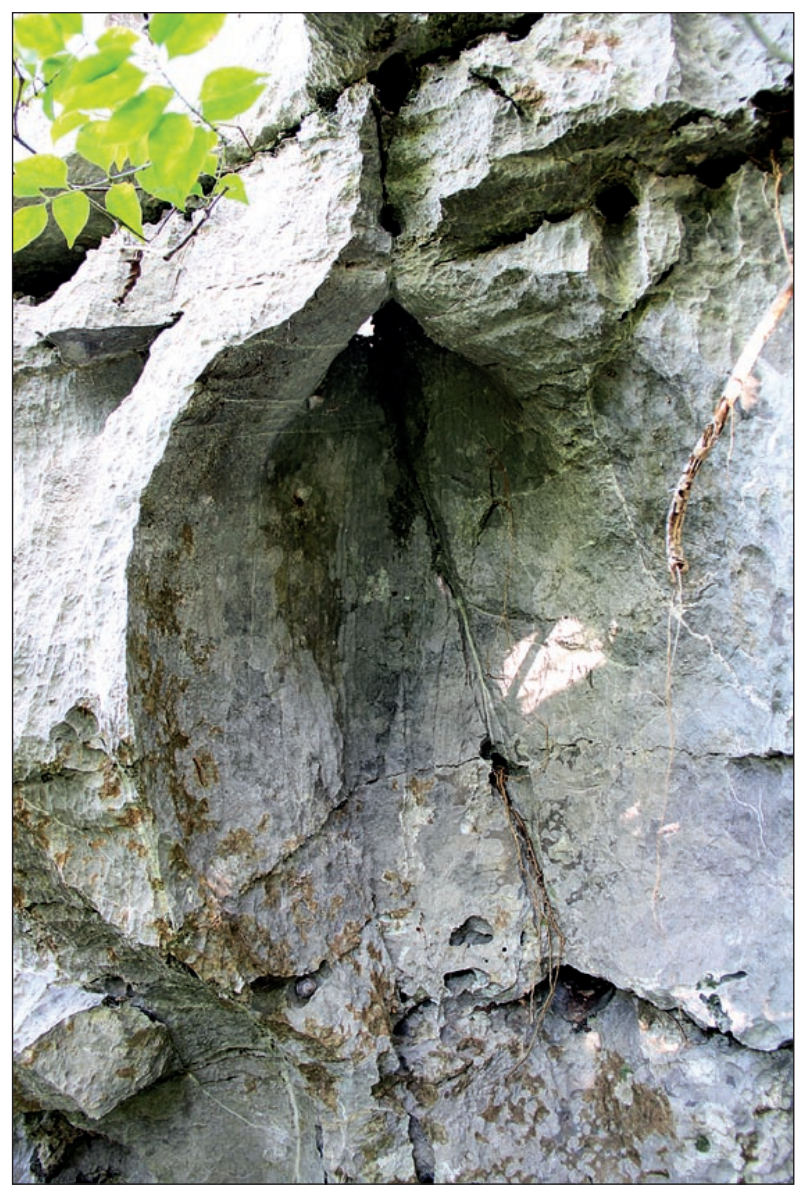

Fig. 4: Half-bell reshaped by creeping water.

flows of water through the bedding planes, they display distinctive semi-pocket-like dissections. The notches widen the mouths of hollows into horizontally deepened elliptical pockets. As a rule they are distinctive at all contacts of rock strata. Subsoil half-bells (Fig. 3c) also formed immediately below the sediment level that reach one meter in diameter. Along the vertical fissures they are narrower and deeper. Wall channels or shafts, mostly along fissures, lead to them. The latter have more distinct bell shapes. When they cross several rock strata with porous bedding planes they display a number of stories, and sometimes a smaller feature indents into the wall of a larger feature below a flow of water from a lower bedding plane. The most distinct subsoil forms are found immediately above the current level of sediment that surrounds the rock. Older and in most cases more distinctly reshaped subsoil notches, shafts, and half-bells (Fig. 4) can be found along the entire cross-section of the mogote. The subsoil-formed rock is rounded and relatively smooth.

\section{TRANSFORMATION OF PRIMARY SUBSOIL ROCK RELIEF}

The tops and upper parts of the slopes are completely dominated by rock forms that are the trace of water creeping down the inclined surface under the soil and weathered debris which covers the rock in places or on the denuded rock. After the denudation of this part of the mogote's surface, further overgrowing did not occur or was quite rare. Rainwater began to reshape the rock and dissect it with flutes and channels. Later multiple periods of overgrowing fostered the deposit of plant remains on the more gently sloping or lower sections of the rock, which only then started to dissect under the weathered debris. Subsoil channels and flutes formed (Fig. 5). Their

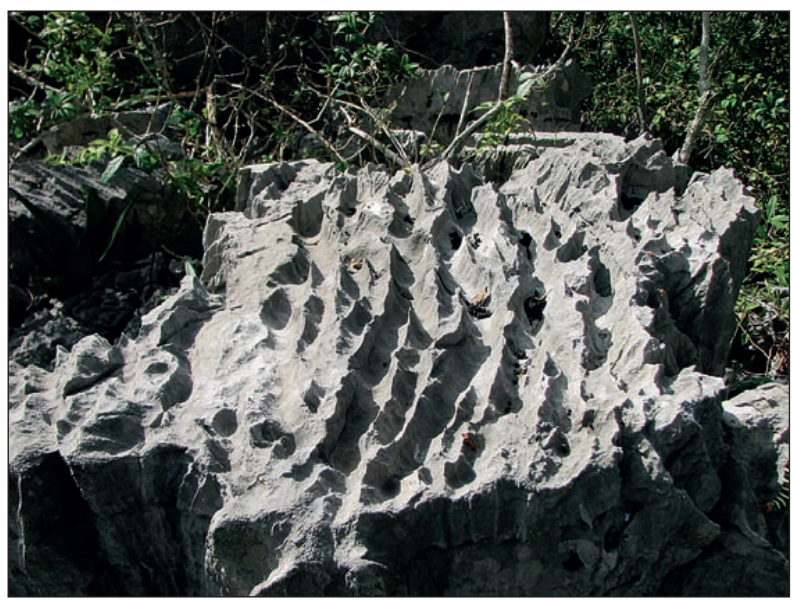

Fig. 5: Subsoil channels.

shape was dictated by the heritage of the rock formation or its frequent denudation. Under the dense vegetation in the conditions evident on the lower section of the slope of the mogote, that is, on the rock and even on the sloping surfaces, subsoil cups dominate completely. In the upper section the rock relief is therefore composite and formed due to the changing conditions in the rock formation. Thus ridges and spikes usually have rain flutes and 
the channels below them have often been reshaped under soil with cross-sections resembling an upside down omega letter, which as a rule applies to the largest (Fig. 6). Their diameters range from one to ten centimeters. The walls of the funnel-shaped notches dissecting the tops of the rock and the more gently inclined channels that were filled with weathered debris are often dissected by subsoil flutes. The water crept evenly down the entire surface under the moist weathered debris. Subsoil forms completely dominate on the tops where vegetation grows. This is a unique system of subsoil channels and flutes.

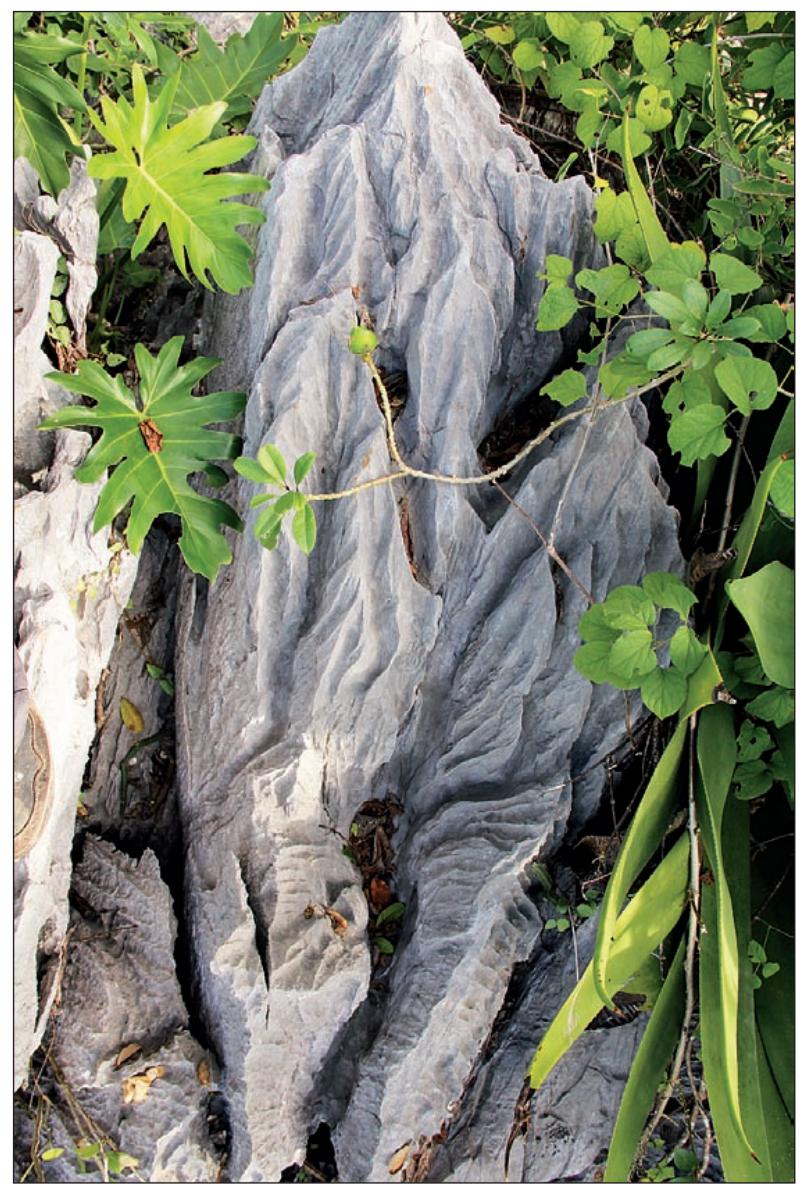

Fig. 6: Rain flutes and subsoil channels and cups.

Funnel-shaped notches (Fig. 3e), mostly of subsoil origin, are found very frequently at the edges of the tops. They are up to one meter deep with variously wide openings on the outer side. They formed as the mouths of vertical subsoil channels and as the ends of subsoil channels that dissected the extensive rocky tops. Subsoil cups that when denuded form like solution pans or continue into wall channels are often found at their bottoms. Their walls are dissected by smaller subsoil flutes and when denuded for a longer time, by rain flutes. On nearby mog- otes, pockets and cups formed on the ceilings of larger wall notches above the sediment that surrounded the rock. The water percolated through the porous rock to the contact and spread along the mouth of the channel in a bell-shape.

\section{ROCK FORMS, SHAPED BY RAINWATER}

Subsoil forms are reshaped by rainwater and water that trickles down walls and percolates through the rock. Rain flutes (Figs. 3f, 7) are found on rock that has been denuded for a longer time and directly exposed to rain. They dissect the sloping surfaces of pointed tops and the higher sections of the rock of dissected wider rocky tops. On steep sections of the rock they are connected in channels. On the dissected tops, however, the water from flutes collects and runs along channels that are often of subsoil origin and when the karren are more densely overgrown with vegetation they are filled with weathered debris. The flutes therefore typically developed on rock originally shaped below the soil and their interweaving with channels displays traces of this development and show that when the karren was frequently overgrown again by vegetation, they could be refilled with weathered debris. In individual places the flutes are deeper than the average, the result of the majoritiy of the water flowing only along their bottoms while the ridges between them are high. Formerly denuded rock has become overgrown by vegetation.

The solution pans typically developed from more or less denuded subsoil cups.

Strongly representative rock forms develop in the rock relief due to the trickling and creeping of water down walls, both the larger walls of the mogote and the smaller walls of the karren. Individual channels (Fig. 3g) or flutes form beneath bedding planes. The former are larger, measuring one decimeter or more in diameter and several meters in length. Their upper parts have funnelshaped mouths. The latter are smaller, a few centimeters in diameter and a meter in length and lie side by side, connected in a network but not completely identical. They are more distinct in the most conductive sections. They are deeper on more gently sloping upper sections or on bulges on more or less vertical surfaces. The channels thus represent the outflow of the most conductive courses the water carved along the bedding planes and often these smaller hollows were originally formed under the soil, while the flutes occur under evenly permeable bedding planes. Flutes (Fig. 8) also form on the vertical or slightly inclined surfaces beneath smaller overhangs down which larger quantities of water creep and carve scallops. Scallops form on overhanging surfaces, a characteristic trace of creeping water. The water that often flows to overhangs along flutes spreads due to gravity. 


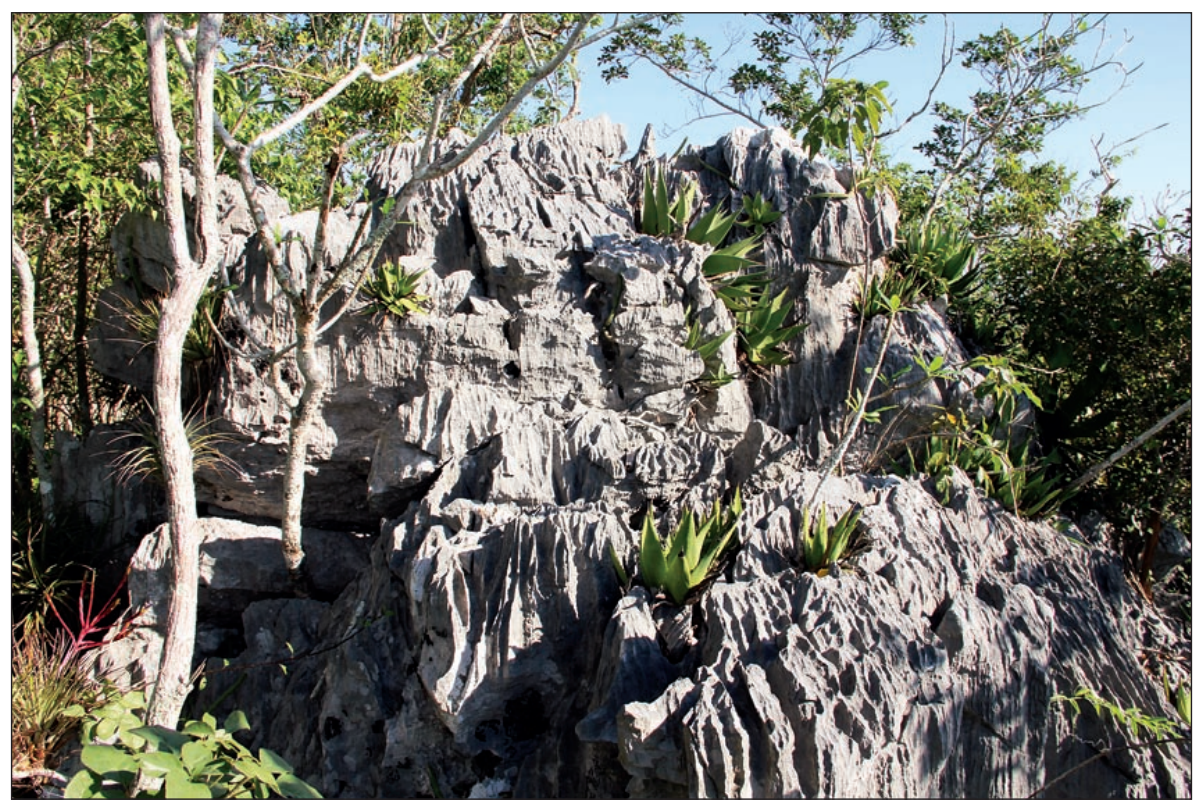

Fig. 7: Rain flutes, channels, funnel-shaped notches, subsoil cups.

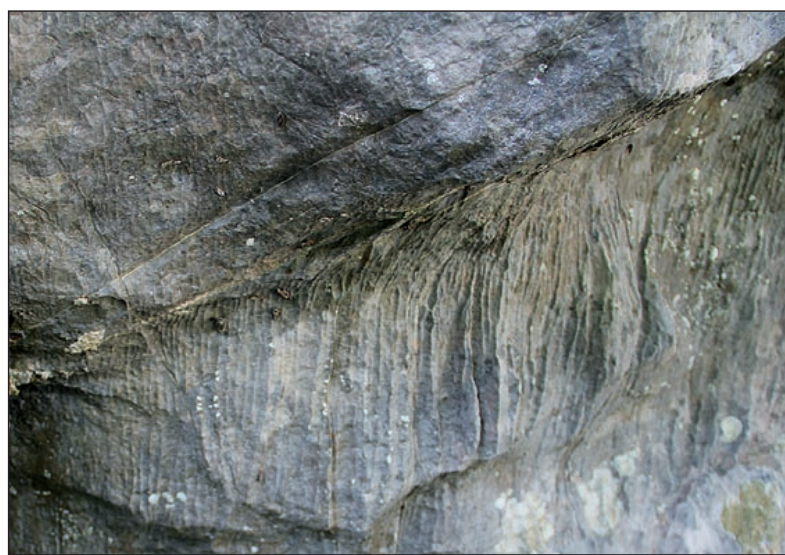

Fig. 8: Flutes, shaped by trickling water.

Wall channels (Fig. 3h) also form below subsoil channels, subsoil cups, or funnel-like notches at edges. Water flows from them and trickles down the walls. Flutes that tend to be deeper than simple rain flutes also form below the tops of ridges that until recently have been covered by weathered debris from which water oozed evenly to their bottoms. The tops therefore have flat and smooth surfaces. They are co-formed by rainwater and water flowing from weathered debris. However, they could also be considered of subsoil origin since it appears they began to form when the entire rock ridges were covered by weathered debris.

Water trickling from open subsoil cups and solution pans on or above the walls leaves traces on the rock. More abundant amounts of water from larger hollows carves channels and smaller amounts of water influence the formation of rock surfaces that are finely porous.

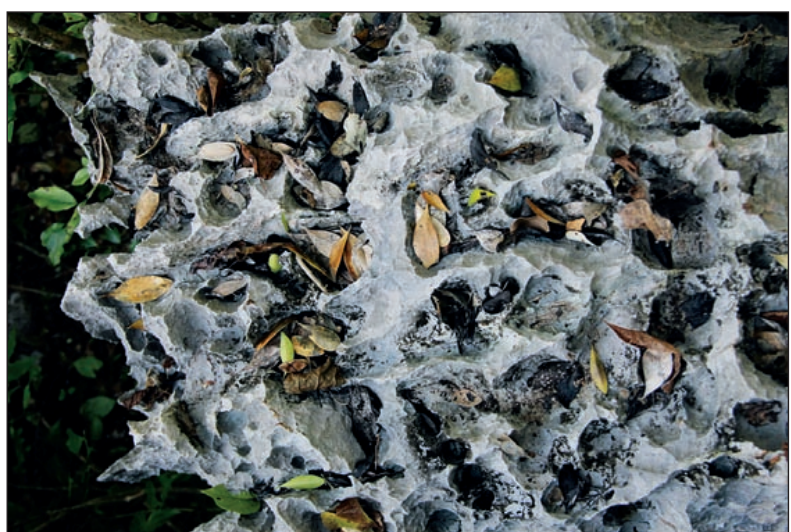

Fig. 9: Subsoil cups.

Water carries weathered debris and deposits it on rough rock.

\section{TYPICAL ROCK FEATURES FORMED UNDER DENSE TROPICAL VEGETATION}

Subsoil cups (Figs. 3d, 9), channels, and flutes that occur below the weathered debris and soil that covers the rock in places add a particular stamp to the unique rock relief of the mogote. With the exception of the north and northwest walls, the steep and more gradually sloping slopes of the described mogote are densely overgrown with trees and brush. Vegetation grows in every fissure and bedding plane of the wall as well. The vegetation is particularly dense on the lower part of the mogote and sparser at the top where larger patches of rock are exposed to the direct impact of rainwater. Beneath the dense vegetation the bare rock sticking through the soil is densely dissected 
by subsoil cups (Fig. 3e). They are usually up to $5 \mathrm{~cm}$ in diameter, with a few larger ones that measure up to $10 \mathrm{~cm}$ in diameter. The cups often form three quarters of a circle. The width of their opening is smaller than the diameter of the lower, inner part. This form is the result of moisture being retained by the weathered debris and the corrosion of the rock under and alongside it. Larger cups have flat bottoms as a rule or their bottoms are dissected by smaller cups. They are found both individually or connected since they grow into each other. On sloping surfaces they are usually open on the outer side of the rock, and a series of small steps can form from a string of completely open cups. The cups first dissect a relatively flat subsoil rock form, while long-term dissection of the rock results in the formation of dissected and ten-centimeter tall points between them. The higher rocky tops that have been exposed to this type of transformation for a long time seem to be the most distinctly dissected. The majority of the cups contain weathered debris, soil, decaying leaves, and in some places water as well.

Subsoil cups are rarely found on the upper part of the rock relief where the rocky mogote has been mostly denuded for a long time. Individual cups can only be found in the more gently sloping sections of channels and bottoms of funnel-like notches, the former mouths of subsoil channels. Most of them have been transformed into solution pans; however, if the cups occur on the walls, the water flows in and out of them along wall channels. In the middle section of the mogote we can trace a more distinct intertwining of rock forms, some created by rainwater and some that form under weathered debris. They are thus found also among the rain flutes. The rock is overgrown but the vegetation is not dense and has not been there for a long time.

\section{CONCLUSION}

The Felo Pérez mogote is located in the Viñales Valley, a karst polje developed between the Sierra de los Organos mountain range and the hills of Pizarras del Sur in Pinar del Río province and is known for its typical surface karst landforms and its large caves. In the case of the Felo Pérez mogote, the rocks belong to the Tumbadero Member, one of the members of the Guasasa Formation which consists of micritic limestones and sandstones. Throughout the studied geological column the rock is very uniform. Micritic limestone (mudstone) dominates and in most cases is heavily tectonically crushed. Recrystallized whole and particle fossil remains were found in only two layers. Stylolites were identified in the majority of the taken samples. With use of the complexometric titration method it was established that the total carbonate in all the samples from the profile exceeds $96.5 \%$. All the samples also contain a significant amount of dolomite and insoluble residue. The beds in the entire geological profile that compose the mogote responded in a similar way to karstification.

The original subsoil development of the mogote reveals a relatively dense system of subsoil hollows that today are mostly empty since the water that penetrates the rock has washed most of the sediment from them. The rocky surface of the mogote is also of subsoil origin.
Subsoil rock forms are most distinctly preserved at the lower edge of the mogote that is surrounded by periodically flooded alluvium and in the notches on the slopes where the sediment remained the longest. In the upper section that has been denuded the longest, characteristic rock forms were shaped by rainwater. They cover the subsoil rock relief and in places intertwine with it.

Under the dense vegetation that covers the karren and whose remains are deposited on it, the rock is being reshaped in a unique manner. Its entire surface is dissected by cups that formed under the weathered debris. These rock forms are also found on sections of the mogote where the traces of rainwater dominate. It appears that the top of the mogote has been alternately overgrown or denuded. Most recently, traces of rainwater have dominated.

In summary, we can trace the gradual denudation of the mogote and the reshaping of the rock relief from subsoil forms to those attributed to rainwater on the longest denuded and only sporadically overgrown surfaces at the top and to those on the lower section of the gentler slopes that form under thick vegetation. The latter give the rock relief a most distinctive and special seal characteristic of this type of rock formation. 


\section{ACKNOWLEDGEMENT}

Research was included in UNESCO IGCP project No. 598.

\section{REFERENCES}

Acevedo González, M., 1971: Geomorfología de Sumidero y sus inmediaciones. Sierra de los Órganos, Pinar del Río, Cuba.- Rev. Tecnológica, 9, 3-4, 33-54.

Acevedo González, M. \& M. R. Gutiérrez Domech, 1974: El Sistema Cavernario Majaguas-Cantera, Pinar del Río, Cuba.- Bol. Soc. Venezolana Espel., 5, 10, 125-142.

Díaz Otero, C., Furrazola, G., Gutiérrez Domech, M. R. \& A. I. Torres, 2002: Léxico Estratigráfico de Cuba. Inédito.- Archivo Instituto de Geología y Paleontología, pp. 348, La Habana.

Gradzinski, R. \& A. Radomski, 1963: Types of Cuban caves and their dependence on factor controlling karst development.- Bull Acad. Polonaise Sc. Serv. Sci. Geol. and Geograf., 13, 2, 181-186.

Gutiérrez Domech, M. R. \& M. Iturralde-Vinent, 1990: Condiciones geológicas de formación del carso en Cuba.- Memorias Congreso Internacional, Aniversario de lla Sociedad Espeleológica de Cuba, pp. 86, La Habana.

Gutiérrez Domech, M. R. \& M. Rivero Glean, 1997: Mini Geografía de Cuba.- Editorial Científico-Técnica, pp. 142, La Habana.

Gutiérrez Domech, M. R. \& M. Rivero Glean, 1999: Regiones Naturales de la isla de Cuba.- Editorial Científico-Técnica, pp. 145, La Habana.

Gutiérrez Domech, M. R., Guerra Oliva, M., Lavandero Illera, R., Pérez, Aragón, R. O., Triff Oquendo, J. \& R. Seco Hernández, 2011: Memoria Explicativa. Mapa de Formas Cársicas de la República de Cuba (1: 250 000).- Archivo Instituto de Geologia y Paleontologia, La Habana.
Herrera, N. M., 1961: Contribucion a la estratigrafia de la provincia de Pinar del Rio.- Soc. Cubana de Ing. Rev, 61, 1-2, 2-24.

Iturralde-Vinent, M., 1988: Naturaleza geológica de Cuba.- Editorial Científico-Técnica, pp. 146, La Habana.

Knez, M. \& T. Slabe, 2009: Lithological characteristics, shape, and rock relief of the Lunan stone forests.In: Ginés, Á., Knez, M., Slabe, T. \& W. Dreybrodt (eds.) Karst rock features : karren sculpturing, ZRC Publishing, Carsologica 9, 439-452, Ljubljana.

Palmer, R. H., 1945: Outline of the Geology of Cuba.Journ. Geology, 53, 1, 1-34.

Piotrowska, K., 1978: Nappe structures in the Sierra de los Organos, Western Cuba.- Acta Geológica Polonica, 28, 1, 97-170.

Slabe, T. \& H. Liu, 2009: Significant subsoil rock forms.In: Ginés, Á., Knez, M., Slabe, T. \& W. Dreybrodt (eds.) Karst rock features : karren sculpturing, ZRC Publishing, Carsologica 9, 123-137, Ljubljana.

Slabe, T. \& M. Knez, 2004: Kraške podtalne skalne oblike.- Annales, Ser. hist. nat., 14, 2, 259-266. 